\title{
PEMGARUH PENGGUNAAN MODEL PEMBELAJARAN KONTEKSTUAL TERHADAP HASIL BELAJAR SISWA MATA PELAJARAN GEOGRAFI DI SMA NEGERI 1 SIANTAN
}

\author{
Agus Suwarno $^{1}$, Supriati ${ }^{2}$ \\ ${ }^{1,2}$ Program Studi Pendidikan Geografi \\ Fakultas Ilmu Pendidikan dan Pengetahuan Sosial IKIP PGRI Pontianak \\ Jalan Ampera Nomor 88 Pontianak - 78116, Telepon (0561) 748219 Fax. (0561) 589855 \\ Alamat e-mail: agoessja@gmail.com
}

\begin{abstract}
Abstrak
Masalah umum dalam penelitian ini adalah bagaimanakah pengaruh penggunaan model pembelajaran kontekstual terhadap hasil belajar siswa pada mata pelajaran geografi di kelas XI SMA Negeri 1 Siantan Kabupaten Mempawah? Dengan sub masalah yaitu: (1) Bagaimanakah hasil belajar siswa sebelum menggunakan model pembelajaran kontekstual pada mata pelajaran geografi di kelas XI SMA Negeri 1 Siantan Kabupaten Mempawah? (2) Bagaimanakah hasil belajar siswa setelah menggunakan model pembelajaran kontekstual pada mata pelajaran geografi di kelas XI SMA Negeri 1 Siantan Kabupaten Mempawah? (3) Apakah terdapat pengaruh penggunaan model pembelajaran kontekstual terhadap hasil belajar siswa pada mata pelajaran geografi di kelas XI SMA Negeri 1 Siantan Kabupaten Mempawah?. Metode yang digunakan dalam penelitian ini adalah metode eksperimen dengan bentuk penelitian pre-exsperimental design. Berdasarkan hasil pengolahan data dan perhitungan statistik secara umum dapat disimpulkan bahwa terdapat pengaruh penggunaan model pembelajaran kontekstual terhadap hasil belajar siswa pada mata pelajaran geografi di kelas XI SMA Negeri 1 Siantan Kabupaten Mempawah yaitu berdasarkan perhitungan diketahui bahwa $t_{\text {Hitung }}>t_{\text {Tabel }}$.
\end{abstract}

Kata Kunci: Model Kontekstual, Hasil Belajar, Mata Pelajaran Geografi

Abstract

The general problem in this research is how the influence of contextual learning models on student learning outcomes in geography subjects in class XI of SMA Negeri 1 Siantan in Mempawah Regency? With the sub-problems, namely: (1) What is the student learning outcomes before using contextual learning models in geography subjects in class XI of SMA Negeri 1 Siantan, Mempawah Regency? (2) What is the result of student learning after using a contextual learning model on geography subjects in class XI of SMA Negeri 1 Siantan, Mempawah Regency? (3) Is there any influence on the use of contextual learning models on student learning outcomes in geography subjects in class XI of SMA Negeri 1 Siantan in Mempawah Regency? The method used in this reseach is an experimental method with preexperimental design. Based on the results of data processing and statistical calculations in general it can be concluded that there is an effect of the use of contextual learning models on student learning outcomes in geography subjects in class XI of SMA Negeri 1 Siantan, Mempawah Regency. Based on calculations known that $\mathrm{t}_{\text {Hitung }}>\mathrm{t}_{\text {Tabel }}$.

Keywords: Contextual Model, Learning Outcome, Geography

\section{PENDAHULUAN}


Negara Indonesia sebagai negara yang berkembang dalam pembangunan membutuhkan sumber daya manusia berkualitas yang dapat diandalkan. Salah satu usaha untuk menciptakan sumber daya manusia berkualitas yang dapat diandalkan adalah melalui pendidikan. Pendidikan merupakan hal yang mendasar yang berkaitan dengan pembentukan kualitas sumber daya manusia, karena melalui pendidikan, manusia diajarkan dan dididik untuk menjadi tahu akan segala hal yang berkaitan dengan ilmu pengetahuan dan teknologi, serta manusia dituntut untuk menguasai hal tersebut demi berlangsungnya kehidupan kearah yang lebih baik, serta dalam persaingan dengan negara lainnya. Oleh karena itu pendidikan merupakan yang paling utama, maka perlunya perbaikan dalam menjalankan sistem pendidikan di Indonesia yang sesuai dengan era modernisasi yang berlangsung pada saat ini, hal tersebut bertujuan untuk menciptakan sumber daya manusia yang berkualitas serta memiliki daya saing, baik itu ditingkat nasional maupun ditingkat internasional. Upaya yang harus dilakukan dalam merealisasikan pendidikan yang berkualitas tersebut adalah melalui proses belajar mengajar di sekolah, karena proses belajar mengajar tersebut merupakan hal yang paling mendasar dalam dunia pendidikan.

Belajar adalah perubahan tingkah laku sebagai akibat dari adanya interaksi antara stimulasi dan respon. Dengan kata lain, belajar merupakan bentuk perubahan yang dialami siswa dalam hal kemampuannya untuk bertingkah laku dengan cara yang baru sebagai hasil interaksi antara stimulus dan respon. Seseorang dianggap telah belajar sesuatu jika ia dapat menunjukan perubahan tingkah lakunya. Dimyati (2015: 9) menyatakan bahwa: "Belajar merupakan suatu prilaku, pada saat orang belajar maka responnya menjadi lebih baik. Sebaliknya bila ia tidak belajar maka responnya menurun.

Proses belajar megajar yang dilaksanakan memerlukan bahan-bahan yang mendukung. Bahan-bahan pendukung pembelajaran tersebut berupa sarana dan prasarana yang ada di sekolah yang bersangkutan, baik itu berupa ruang kelas yang memadai, proyektor, dan media-media pendukung pembelajaran yang lainnya. Sarana dan prasarana tersebut merupakan bahan pendukung proses belajar mengajar yang bertujuan dalam meningkatkan hasil belajar siswa. 
Salah satu indikasi pencapaian proses pendidikan di sekolah dapat dilihat dari hasil belajar siswa. Hasil belajar merupakan salah satu indikator keberhasilan baik bagi seorang guru maupun bagi siswa. Bagi seorang guru, hasil belajar siswa dapat dijadikan sebagai pedoman penilaian terhadap prestasi dalam kegiatan pembelajaran siswa. Sedangkan bagi siswa hasil belajar merupakan informasi yang berfungsi untuk mengukur tingkat kemampuan atau prestasi belajarnya, apakah mengalami perubahan yang bersifat positif maupun perubahan yang bersifat negatif.

Selain itu juga dalam proses belajar mengajar, guru menggunakan modelmodel pembelajaran dalam menyampaikan materi pembelajarannya, karena hal tersebutlah yang membantu guru dalam proses belajar mengajar di kelas. Model pembelajaran merupakan sebuah pedoman bagi guru dalam merencanakan pembelajaran di kelas. Jadi, model pembelajaran adalah seluruh rangkaian penyajian materi ajar yang meliputi segala aspek sebelum sedang dan sesudah pembelajaran yang dilakukan guru serta segala fasilitas yang terkait yang digunakan secara langsung atau tidak langsung dalam proses belajar mengajar. Adapun tujuan dari adanya model pembelajaran yang digunakan oleh guru adalah untuk membantu guru dalam mempersiapkan pelaksanaan pembelajaran di kelas, dan dengan adanya model pembelajaran, guru dapat merumuskan tujuan pembelajaran dan tahap-tahap dalam setiap pembelajaran yang akan dilaksanakan.

Banyak sekali model pembelajaran yang bisa digunakan oleh guru dalam proses belajar mengajar dan tergantung dengan materi pelajaran yang akan disampaikan kepada siswa dan juga perlunya model pembelajaran yang tepat dalam menyampaikan sebuah materi salah satunya yaitu dalam mata pelajaran geografi. Geografi adalah ilmu yang mempelajari persamaan dan perbedaan fenomena geosfer dengan sudut pandang kewilayahan/kelingkungan dalam konteks keruangan. Ditinjau dari segi etimologi atau asal kata geografi berasal dari bahasa Yunani yang terdiri atas dua kata yaitu geo yang berarti bumi, graphein yang berarti gambaran/lukisan. Gabungan dua kata tersebut membentuk kata baru geographein yang berarti gambaran/lukisan tentang bumi. 
Satu diantara model pembelajaran tersebut adalah model pembelajaran kontekstual. Model pembelajaran kontekstual merupakan model pembelajaran yang mengaitkan antara materi pembelajaran dengan konteks dunia nyata, yang mana pada pembelajaran ini, guru dan peserta didik dituntut untuk mengaitkan materi pembelajaran dengan hal yang sesungguhnya yang terjadi dilapangan. Pembelajaran menjadi lebih bermakna dan riil. Artinya siswa dituntut untuk dapat menanggap hubungan antara pengalaman belajar di sekolah dengan kehidupan nyata. Hal ini sangat penting, sebab dengan dapat mengorelasikan materi yang ditemukan dengan kehidupan nyata, bukan saja bagi siswa materi itu akan berfungsi secara fungsional, akan tetapi materi yang dipelajarinya akan tertanam erat dalam memori siswa, sehingga tidak akan mudah dilupakan. Pembelajaran kontekstual juga merupakan pembelajaran yang lebih produktif dan mampu menumbuhkan penguatan konsep kepada siswa, pembelajaran yang menekankan pada aktifitas siswa secara penuh, baik fisik maupun mental, dalam pembelajaran kontekstual merupakan sebagai tempat untuk menguji data hasil temuan siswa dilapangan dan bukan hanya hasil pemberian dari guru, serta penerapan pembelajaran kontekstual dapat menciptakan suasana pembelajaran yang bermakna.

Berdasarkan penjelasan di atas, maka dapat disimpulkan bahwa model kontekstual ini cocok digunakan dalam proses belajar mengajar di sekolah manapun juga, karena model pembelajaran kontekstual merupakan suatu model pembelajaran yang mengaitkan antara materi pembelajaran dengan konteks dunia nyata siswa. Sekolah yang menjadi tempat penelitian terkait dengan penggunaan model pembelajaran kontekstual adalah SMA Negeri 1 Siantan Kabupaten Mempawah. Sejalan dengan fakta di lapangan yang menunjukan kegiatan proses belajar mengajar lebih banyak diorientasi oleh guru sebagai sumber belajar. Guru mengontrol secara penuh materi dan metode penyampaian. Akibatnya proses pembelajaran kurang melibatkan peran siswa secara aktif. Siswa hanya mengikuti hal-hal yang dicontohkan oleh guru sehingga proses pembelajaran lebih menekankan pada kemampuan untuk mengingat atau menghafalkan dan menekankan pada pemahaman materi dengan menghubungkan pada lingkungan 
sekitar anak. Sebagian besar siswa tidak mampu menghubungkan antara apa yang mereka pelajari dengan bagaimana pengetahuan tersebut akan dipergunakan/dimanfaatkan. Siswa memiliki kesulitan untuk memahami konsep akademik sebagaimana mereka diajarkan, yaitu menggunakan sesuatu yang abstrak dan metode ceramah. Karena ketidak sesuaian antara model pembelajaran dengan dengan materi yang dijelaskan oleh guru, hal ini juga berdampak pada rendahnya nilai siswa ketika dilakukan tes. Dari banyaknya permasalah dalam dunia pendidikan, khususnya dalam proses pembelajaran di kelas yang berdampak pada rendahnya hasil belajar siswa. Mereka sangat butuh untuk memahami konsep-konsep yang berhubungan dengan tempat kerja dan masyarakat pada umumnya dimana mereka akan hidup dan bekerja.

Melalui pengamatan di kelas, pembelajaran lebih didominasi oleh guru sebagai sumber belajar sehingga kurang memberikan kesempatan kepada siswa untuk mengembangkan kemampuan yang dimilikinya. Padahal guru bukanlah satu-satunya sumber belajar bagi siswa, sumber belajar dapat berupa lingkungan dan masyarakat sekitar.

Masalah umum dalam penelitian ini adalah Bagaimanakah Pengaruh Penggunaan Model Pembelajaran Kontekstual Terhadap Hasil Belajar Siswa Pada Mata Pelajaran Geografi Di Kelas XI SMA Negeri 1 Siantan Kabupaten Mempawah?. Dengan sub masalah yaitu: (1) Bagaimanakah Hasil Belajar Siswa Sebelum Menggunakan Model Pembelajaran Kontekstual Pada Mata Pelajaran Geografi Di Kelas XI SMA Negeri 1 Siantan Kabupaten Mempawah? (2) Bagaimanakah Hasil Belajar Siswa Setelah Menggunakan Model Pembelajaran Kontekstual Pada Mata Pelajaran Geografi Di Kelas XI SMA Negeri 1 Siantan Kabupaten Mempawah? (3) Apakah Terdapat Pengaruh Penggunaan Model Pembelajaran Kontekstual Terhadap Hasil Belajar Siswa Pada Mata Pelajaran Geografi Di Kelas XI SMA Negeri 1 Siantan Kabupaten Mempawah?

\section{METODE}

Metode yang digunakan dalam penelitian ini adalah metode eksperimen. Metode penelitian eksperimen dapat diartikan sebagai metode penelitian yang 
digunakan untuk mencari pengaruh perlakuan tertentu terhadap yang lain dalam kondisi yang terkendalikan (Sugiyono, 2013: 107). Digunakan Metode Eksperimen dalam penelitian ini karena sesuai dengan penelitian ini yakni untuk melihat hasil belajar siswa di kelas XI SMA Negeri 1 Siantan Kabupaten Mempawah pada mata pelajaran Geografi melalui Model Pembelajaran Kontekstual. Berdasarkan rumusan masalah yang diangkat dalam penelitian ini maka penelitian ini menggunakan penelitian Pre-Experimental Design.

"Dikatakan Pre-Experimen Design, karena desain ini belum merupakan eksperimen sungguh-sungguh. Mengapa? Karena masih terdapat variabel luar yang ikut berpengaruh terhadap terbentuknya variabel dependen”. (Sugiyono, 2013: 109). Adapun bentuk penelitian yang digunakan dalam penelitian ini adalah menggunakan One-Group Pretest-Posttes Design, One-Group. Pretest-Posttes Design adalah jika pada desain lain tidak ada pretest, maka pada desain ini terdapat pretest, sebelum diberi perlakuan. Dengan demikian hasil perlakuan dapat diketahui lebih akurat, karena dapat membandingkan dengan keadaan sebelum diberi perlakuan. Adapun populasi dalam penelitian ini adalah "Seluruh siswa kelas XI SMA Negeri I Siantan Kabupaten Mempawah

Teknik pengumpul data yang digunakan adalah studi dokumenter, dan teknik pengukuran. Teknik studi dokumenter digunakan dalam penelitian ini, dikarenakan peneliti bermaksud untuk melihat dokumen-dokumen seperti silabus, Rencana Pelaksanaan Penelitian (RPP), dan dokumen yang lainnya. Hal ini bertujuan untuk menunjang data dalam penelitian ini. Teknik pengukuran digunakan dalam penelitian ini adalah dengan menggunakan tes. Dalam penelitian ini digunakan teknik pengukuran, karena pada penelitian ini bertujuan untuk mengetahui hasil belajar siswa, yang diberikan skor terhadap hasil belajar yang diperoleh siswa pada mata pelajaran geografi di kelas XI IPS 2 SMA Negeri 1 Siantan Kabupaten Mempawah.

Adapun populasi dalam penelitian ini adalah "Seluruh siswa kelas XI SMA Negeri I Siantan Kabupaten Mempawah yaitu terdiri dari 5 kelas yang masing-masing kelasnya berjumlah 40 orang. Dalam menentukan sampel pada penelitian ini, teknik yang digunakan oleh peneliti adalah teknik Nonprobability 
Sampling dengan cara Sampling Purposive. Sugiyono (2013: 122) menyatakan bahwa "Nonprobability Sampling adalah teknik pengambilan sampel yang tidak memberi peluang/kesempatan sama bagi setiap unsur atau anggota populasi untuk dipilih menjadi sampel”. Sedangkan Sampling Purposive adalah teknik penentuan sampel dengan pertimbangan tertentu. Penentuan sampel dalam penelitian ini berdasarkan pertimbangan tertentu, yaitu berdasarkan hasil belajar siswa yang rendah diantara kelas-kelas lainnya yang menjadi populasi penelitian. Adapun sampel dalam penelitian ini adalah siswa kelas XI IPS 2 SMA Negeri 1 Siantan Kabupaten Mempawah, berjumlah 40 orang siswa, yang dilihat darinilai ulangan harian siswa yaitu dengan rata-rata 56,87.

Mengolah data hasil sebuah penelitian, maka diperlukannya teknik untuk menganalisis datanya, teknik tersebut bisa disebut dengan teknik analisis data. Pada penelitian ini termasuk pada penelitian kuantitatif, oleh karena itu dalam mengolah data atau menganalisis datanya dengan menggunakan rumus statistik. Berdasarkan rumusan masalah yang terdapat dalam penelitian ini, maka langkahlangkah dalam menganalisis data yang diperoleh berdasarkan penelitian di lapangan, menggunakan rumus sebagai berikut:

(1) Menjawab sub masalah nomor 1 dan 2 yaitu untuk mengetahui hasil belajar siswa sebelum dan sesudah menggunakan model pembelajaran kontekstual terhadap hasil belajar siswa pada mata pelajaran geografi di kelas XI SMA Negeri 1 Siantan Kabupaten Mempawah, dengan menggunakan rumus ratarata hitung (Mean), Rahayu Kariadinata (2012: 65) sebagai berikut:

$$
\bar{X}=\frac{X_{1}+X_{2}+\cdots+X_{n}}{n}
$$

(2) Menjawab sub masalah nomor 3 yaitu untuk mengetahui pengaruh penggunaan model pembelajaran kontekstual terhadap hasil belajar siswa pada mata pelajaran geografi di kelas XI SMA Negeri 1 Siantan Kabupaten Mempawah. Menggunakan rumus t-test menurut Zuldafrial (2012: 131), adapun rumus yang digunakan tersebut adalah sebagai berikut: 


$$
\mathbf{t}_{\mathbf{0}}=\frac{\mathrm{MD}}{\mathrm{SE}_{\mathrm{MD}}}
$$

$\mathrm{MD}=$ Mean of Differences $=$ Nilai rata-rata hitungan dari beda/selisih antara skor variabel I dan skor variabel II, yang dapat diperoleh dengan rumus:

$$
\mathbf{M D}=\frac{\sum \mathbf{D}}{\mathbf{N}}
$$

$\sum E D=$ Jumlah beda/selisih antara skor variabel I (variabel $\mathrm{X}$ ) dan skor variabel II (variabel II) dan D dapat diperoleh dengan rumus: $\mathrm{D}=\mathrm{X}-\mathrm{Y}$ $\mathrm{N}=$ Number of case/jumlah subyek yang kita teliti.

$\mathrm{SE}_{\mathrm{MD}}=$ Standar error (standar kesesatan) dari Mean of differences yang dapat diperoleh dengan rumus:

$$
\frac{\mathrm{SE}_{\mathrm{MD}}}{\sqrt{\mathrm{N}-\mathbf{1}}}=\mathrm{SD}_{\mathrm{D}}
$$

$S D_{D}=$ Deviasi standar dari perbedaan antara skor variabel I dengan skor variabel II yang dapat diperoleh dengan rumus:

$$
\operatorname{SD}_{\mathrm{D}}=\sqrt{\frac{\sum \mathbf{D}^{2}}{\mathrm{~N}}-\frac{\left(\sum-\mathbf{D}\right)^{2}}{\mathrm{~N}}}
$$

\section{HASIL DAN PEMBAHASAN}

Pelaksanaan penelitian dilakukan dari tanggal 7 september sampai dengan 26 september, dimulai dari pemberian pretest kepada siswa untuk mengetahui hasil belajar siswa sebelum diterapkannya model pembelajaran kontekstual, kemudian memberikan percobaan kepada kelas yang menjadi sampel penelitian dengan menggunakan model pembelajaran kontekstual, dan kemudian memberikan posttest kepada siswa untuk mengetahui hasil belajar setelah diterapkannya model pembelajaran kontekstual pada mata pelajaran geografi. Berdasarkan hasil pengolahan data penelitian, diperoleh informasi sebagai berikut: 
(1) Rata-rata hasil pretest atau sebelum diterapkannya model pembelajaran kontekstual pada mata pelajaran kontekstual adalah 71,25. (2) Rata-rata hasil posttest atau setelah diterapkannya percobaan dengan menggunakan model pembelajaran kontekstual pada mata pelajaran kontekstual adalah 77,12 . (3) Penerapan model pembelajaran kontekstual pada mata pelajaran geografi berpengaruh terhadap hasil belajar siswa, yang dihitung dengan menggunakan tumus t-tes, adapun perhitungan tersebut menunjukan bahwa $t_{\text {Hitung }}>t_{\text {Tabel }}$, yaitu $4,753>2,70$.

Namun dalam penelitian ini juga terdapat beberapa kelemahan, adapun kelemahan-kelemahan tersebut adalah: (1) Terdapat beberapa siswa yang sering membuat keributan dalam proses belajar mengajar berlangsung, sehingga akan menganggu guru dalam menjelaskan pembelajaran dan menganggu siswa yang lain yang serius dalam mengikuti proses belajar mengajar, serta berdampak pada pemahaman siswa terhadap materi yang disampaikan oleh peneliti. (2) Kurangnya media pembelajaran yang dibutuhkan dalam menunjang proses pembelajaran. (3) Proses pembelajaran dengan menggunakan model pembelajaran kontekstual, memerlukan waktu yang lebih lama dibandingkan dengan alokasi pembelajaran yang diberikan. Walaupun secara umum pembelajaran dapat berlangsung atau terlaksana, namun masih belum bisa maksimal. (4) Pada pembelajaran dengan menggunakan model pembelajaran kontekstual peneliti harus lebih ekstra dalam menyampaikan materi pelajaran karena pada model pembelajaran ini siswa dituntut untuk aktif, baik dalam bertanya dan menjawab pertanyaan dari guru serta siswa yang lainnya. (5) Peneliti harus memicu agar suasana kelas menjadi lebih aktif, tanpa adanya keributan-keributan yang terjadi sehingga akan mengganggu proses belajar mengajar. (6) Ketika menyampaikan materi pembelajaran guru bukan hanya berbicara semata, namun guru harus selalu mengaitkan antara materi dengan konteks dunia nyata siswa dalam kehidupan sehari-hari. Dan juga guru mengajak siswa menerapkannya dalam kehidupan, sesuai dengan materi yang telah diberikan kepada siswa. Dengan cara seperti itu maka akan memicu siswa untuk aktif dalam proses belajar mengajar. 


\section{KESIMPULAN}

Berdasarkan hasil analisis data dari penelitian yang telah dilakukan secara umum dapat disimpulkan bahwa penerapan model pembelajaran kontekstual memiliki pengaruh terhadap hasil belajar siswa pada materi sumber daya alam di kelas XI IPS SMA Negeri 1 Siantan Kabupaten Mempawah. Sesuai dengan rumusan masalah penelitian maka dapat disimpulkan bahwa hasil penelitian ini adalah sebagai berikut: (1) Rata-rata hasil belajar pretest atau sebelum diterapkannya model pembelajaran kontekstual pada mata pelajaran geografi adalah 71,25 yaitu belum mencapai Ketuntasan Minimum KKM 75. (2) Rata-rata hasil belajar posttest atau setelah diberikan percobaan dengan menggunakan model pembelajaran kontekstual pada mata pelajaran geografi adalah 77,12 sudah mencapai Ketuntasan Minimum dengan kriteria sedang yaitu diatas KKM 75.

(3) Terdapat pengaruh penggunaan model pembelajaran kontekstual terhadap hasil belajar siswa pada mata pelajaran geografi di kelas XI SMA Negeri 1 Siantan Kabupaten Mempawah. Hal tersebut dihitung dengan menggunakan rumus t-test. Adapun perhitungan tersebut menunjukan bahwa $t_{\text {Hitung }}>t_{\text {Tabel }}$. Hal ini menunjukan bahwa semakin tepat penggunaan model pembelajaran maka semakin baik pula hasil belajar siswa yang diperoleh. Namun, jika kurang tepat penggunaan model pembelajaran di kelas maka hasil belajar siswa akan stagnan atau relatif menetap.

\section{DAFTAR PUSTAKA}

Dimyati \& Mudjiono. (2015). Belajar dan Pembelajaran. Jakarta: Rineka Cipta. Sugiyono. (2013). Metode Penelitian Pendidikan. Bandung: Alfabeta.

Kariadinata Rahayu. (2012). Dasar-dasar Statistik Pendidikan. Bandung: Pustaka Setia.

Zulfafrial. (2012). Penelitian Kuantitatif. Yogyakarta: Media Perkasa. 